perfect than the maps which are now prepared by Dr. Denison. We doubt if there are half a dozen climatologists in the Union who could give as much information concerning their own locality as could be obtained from these maps. They might be accurately termed "weather calendars." The Annual Map shows the cloudiness, the temperature, rainfall, direction, velocity of winds, and the comparative windiness, elevations above - the sea level, ranges of temperature, relative and absolute humidities, the dew point, and the vapor tension.

The Seasonal Maps show the combined humidities, isotherms, wind-arrows, and seasonal tables. It would be impossible, in a short notice, to show the importance of these items for the physician who is consulted as to the selection of a health resort; but it should suffice to say that one who is ignorant of their importance is as unfit to give advice on this subject as the man who has never studied materia medica and therapeutics is to write a prescription for medicine. To say nothing of their value as sources of information, these maps are the greatest savers of time that one can well imagine; data may be obtained at a glance which would otherwise involve hours of reading, even if the material for the reading could be found.

Dr. Denison has commenced work in a mine which is far more valuable than any of those subterrestrial which have been opened in his native state; for it is a mine which includes the whole of this vast extent of country. The amount of labor that must have been expended upon the preparation of these maps is simply immense. Not only the profession, but the people, both of this country and of those across the waters, owe Dr. Denison a debt of gratitude for his painstaking care and accurate work; and we can but hope that the former, at least, will show their appreciation of his valuable contributions to a much neglected, though vastly important subject. Every physician who has reason to suppose that he will ever send a patient to a health resort should have one of these maps in his office.

\section{ASSOCIATION ITEMS.}

\section{REGISTRATION AT THE ASSOCIATION} MEETING.

We have received the following notice regarding the registration of members and delegates at the next meeting of the American Medical Association:

Members will be registered in the Medical Department of the Tulane University, of Louisiana (Common street, between Baronne and Dryades streets), and adjacent to Tulane Hall, where the general meetings will take place.

Registration will begin on Monday, April 27, and the hours will be from 9 A.M. to I P.M., and from 4 to 6 P.M., daily. In the registration room there will be four desks - one for registering all names from $A$ to $E$; a second, $F$ to $L$; a third, $\mathrm{M}$ to $\mathrm{R}$; and a fourth, $\mathrm{S}$ to $\mathrm{Z}$.

\section{Stanford E. Chaillé.}

\section{RAILROAD FACILITIES TO THE ASSOCIATION MEETING.}

Members and other physicians who anticipate starting from Chicago, or going via Chicago, who are desirous of going on the special limited express train of Pullman Palace Cars that will leave Chicago on the Illinois Central railroad, Saturday evening next (April 25), at 9 o'clock, had better secure their berths at once, to better facilitate the management in Chicago of providing sufficient sleeping-car accommodations, as we understand that excursions from other points will make close connections with this train at various places along the route. The coming meeting in New Orleans gives promise of being an eminently successful one, judging from the number of papers that have already been announced. An unusually large delegation of Chicago physicians have signified their intention of attending this meeting. Among the number will be twenty-eight delegates from the Chicago Medical Society, several of whom will be accompanied by ladies. It may be well to state again that living expenses in New Orleans vary considerably, but the prospects are that all will be amply provided for at a reasonable rate, at places that are convenient to all portions of the city, and where sleeping rooms, with breakfast, may be had. The rest of your meals may be procured down town, or at the Exposition, or elsewhere, as fancy and convenience should suit you. The fare for the round trip from Chicago to New Orleans on this train will be $\$ 20$ for tickets good for fifteen days, or $\$ 25$, with the tickets limited to forty days, with stop-over privileges on returning, etc., etc. The sleeping-car fare is $\$ 6$ for a double berth, or $\$ 12$ for a section.

For further information regarding rates and berths, apply at the ticket office of the general northern passenger agent, Illinois Central Railroad Company, No. I 2 I Randolph St., Chicago.

\section{NECROLOGY.}

\section{JAMES LAWRENCE LITTLE, M.D.}

Our regret in announcing the death of this well known surgeon is but the forerunner of that which will be felt by those who will subsequently read of his death. He died very suddenly, on April 4th, of peritonitis, induced by perforation of the vermiform appendix.

James Lawrence Little, M.D., was born in Brooklyn, in February, I 836 . While studying medicine he was a private pupil in the office of the late Prof. Willard Parker; and he received his degree in medicine from the College of Physicians, of New York, in $186 \circ$, after having previously served in the Bellevue Hospital for six months as Junior Assistant Physician. Imme- 